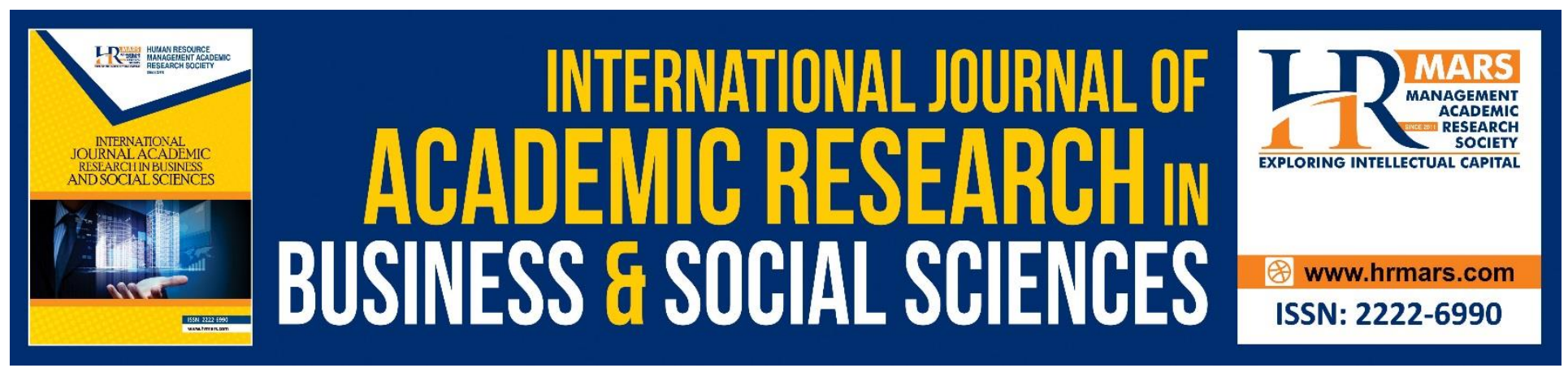

\title{
Does Capital Adequacy Ratio Moderates the Relationship Between Ownership Structure and Performance?
}

\author{
Nasyra Ab. Jamil, Rasidah Mohd. Said
}

To Link this Article: http://dx.doi.org/10.6007/IJARBSS/v8-i10/5300

DOI: $10.6007 /$ IJARBSS/v8-i10/5300

Received: 29 Sept 2018, Revised: 17 Oct 2018, Accepted: 29 Oct 2018

Published Online: 02 Nov 2018

In-Text Citation: (Jamil \& Said, 2018)

To Cite this Article: Jamil, N. A., \& Said, R. M. (2018). Does Capital Adequacy Ratio Moderates the Relationship Between Ownership Structure and Performance? International Journal of Academic Research in Business and Social Sciences, 8(10), 1305-1319.

\section{Copyright: (c) 2018 The Author(s)}

Published by Human Resource Management Academic Research Society (www.hrmars.com)

This article is published under the Creative Commons Attribution (CC BY 4.0) license. Anyone may reproduce, distribute, translate and create derivative works of this article (for both commercial and non-commercial purposes), subject to full attribution to the original publication and authors. The full terms of this license may be seen at: http://creativecommons.org/licences/by/4.0/legalcode

Vol. 8, No. 10, 2018, Pg. 1305 - 1319

Full Terms \& Conditions of access and use can be found at http://hrmars.com/index.php/pages/detail/publication-ethics 


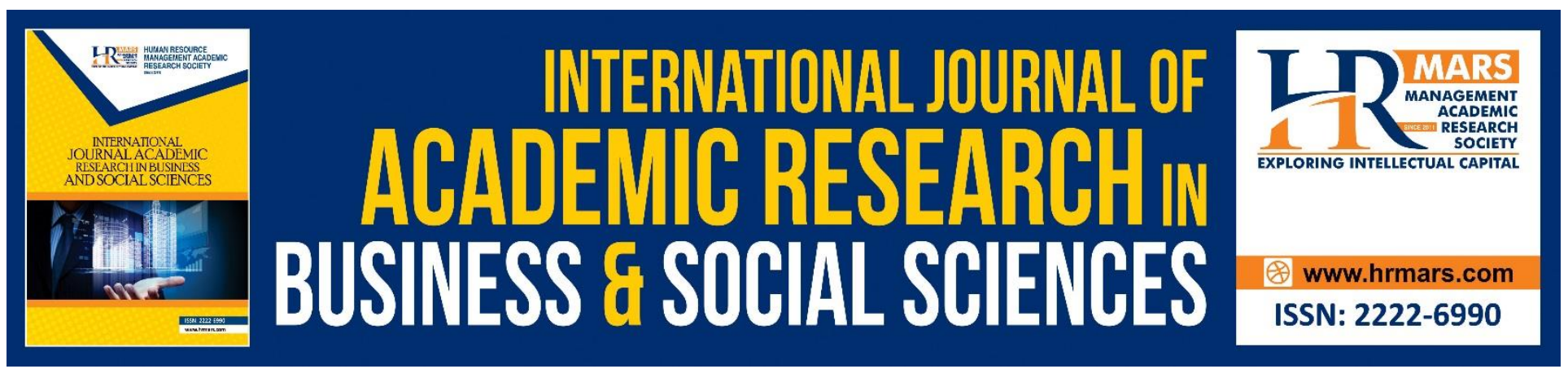

\title{
Does Capital Adequacy Ratio Moderates the Relationship Between Ownership Structure and Performance?
}

\author{
Nasyra Ab. Jamil \\ Faculty of Business, Technology \& Accounting, UNITAR International University, Selangor, Malaysia \\ Rasidah Mohd. Said \\ Graduate School of Business, Universiti Kebangsaan Malaysia, Selangor, Malaysia
}

\begin{abstract}
This research aims to investigate the impact of the three-ownership structure (government, institutional and family) with capital adequacy ratio as the moderating element towards bank performance as measured by return on asset (ROA), return on equity (ROE), and market performance represented by Tobin's $Q$, along with the five control variables. Data from eight Large Domesticallyowned Commercial Banks in Malaysia for the period that runs from 2000 to 2012 are used in this research. Hierarchical moderated multiple regressions methods are applied in this study. Results suggest that capital adequacy is significant as moderating factor of the three ownership structures towards the three bank performances regardless of the mix directions. However, the interaction between the three-ownership structure and capital adequacy are also found to be significant only towards return on equity (ROE).
\end{abstract}

Keywords: Ownership structure, ROA, ROE, Tobin's Q, Banking, Capital Adequacy Ratio

\section{Introduction}

Ownership is important and that it is helpful to view the issue in the context of the principal-agent framework and public choice theory (Altunbas et al. 2001). However, while that literature has provided considerable understanding of the effects of ownership, its primary focus is basically on non-financial firms. The separation of owners (financial provider) from decision maker (manager) creates agency problem between these two entities in the firm. Agency problem arises when shareholders yearn for capital return while the decision maker may misappropriate the shareholders' investment. Agency problem is a source of inefficiency because it explains why environmental pressures, which influence the responses and effort of management, may fail to coerce maximal effort from managers. 
There are ample literature that examines the relationship between industrial ownership and performance, whereby the implications of which can be summarised as follows. The importance of ownership as it is appropriate to consider the ownership-performance nexus in the context of the principal-agent framework. The problems of principal-agent can occur whenever there is separation between ownership and control. These problems may explain differences in the performance of firms with different ownership (Williams \& Nguyen, 2005).

According to Levine (2004), principal-agent problems in banks may raise the issues attributable to what is the most appropriate governance structure for banks. The complicated issues of bank governance is caused by several factors such as the quality of bank regulations and supervision, the opaqueness of bank assets, the level of market development, and the institutional environment which conditions the overall effectiveness of financial markets. lannotta et al (2007) argues that a firm's ownership structure can be defined along two main dimensions. First, the degree of ownership concentration; firms may differ because their ownership is more or less dispersed. Next, the nature of the owners; given the same degree of concentration, two firms may differ if the government holds a majority stake in one of them, which is similarly a stock firm with dispersed ownership is different from a mutual firm. However, the empirical evidence also reveals the situation whereby more concentrated ownership is associated with poorer bank performance (Riewsathirathorn, Jumroenvong, \& Jiraporn, 2011).

Bank stability has been yet again the topmost agenda for the policy makers' agenda across advanced developing countries. This has been a concern since the beginning of the 1997-1998 Asian financial crisis, and for the past few years there has been numerous debates around the world on to the stability of banks of different sizes and ownership (Beck et al 2009). For the past two decades, Malaysia has experienced two financial crisis namely; Asian Financial Crisis in 1997-1998 and the Global Financial Crisis in 2008-2009. The 1997/1998 Asian Financial Crisis has been found to be more severe and have left a bigger impact to Malaysia banking industry as compared to the 2008-2009 Global Financial Crisis. As per Beck et al. (2003) the occurrence of the banking crisis is due to the banking fragility, whereby crises are less likely in economies with more concentrated banking systems. This is because the profits enhanced by the concentrated banking systems do resulted lower bank fragility. The same issue also has been discussed in (Beck et. al 2006).

The aim of this research is to investigate the ownership structure as a mechanism for analysing the determinants of Malaysian bank performance. The main motivating factor of this study is the effect of the 1997/1998 economic crisis. In addition, prior to the situation, the poor bank governance are more severe than that of non-bank firms and their failures have even more significant costs. This is due to banks are considered unique economic units because their distinguishing roles in financial intermediation, in payment system, liquidity, information and maturity and denomination transformation. In line to this, banks are also important as they provide critical monitoring role in the governance of their borrowers such as reducing borrowers' earnings management behaviour as suggested by Ahn \& Choi (2009).

In addition, this study also attempts to investigate the importance of capital adequacy ratio (CAR) as a moderating factor between the ownership structures with the bank performance. Capital adequacy ratio (CAR) is the ratio of a bank's capital to its risk-weighted assets. 
INTERNATIONAL JOURNAL OF ACADEMIC RESEARCH IN BUSINESS AND SOCIAL SCIENCES Vol. 8, No. 10, Oct. 2018, E-ISSN: 2222-6990 @ 2018 HRMARS

The remainder of this paper is organized as follows. Section 2 presents an overview of the literature on bank ownership and performance. Section 3 describes the data and methods employed, Section 4 discusses the results, and finally Section 5 concludes the findings.

\section{Literature Review and Hypotheses Development}

The banking system is the primary mobiliser of funds and also the main source of financing that supports the economic activities in Malaysia. It comprises of commercial banks, investment banks and Islamic banks. In this study, the focus is on the eight domestically-owned commercial banks in Malaysia. This is due to their importance as the largest group of commercial banks and most significant providers of funds in the banking system. Furthermore, commercial banks have the largest share of the market. The classifications of the three main group of the eight commercial banks are as follow: i) Family Owned Banks which comprises of AMMB, HLB, Public Bank and RHB meanwhile, ii) Government Owned Banks consists of Affin, CIMB and Maybank and finally, iii) Alliance Bank Berhad is classified as Corporate Owned Bank.

The worsening situation that have been prompted in some of the banking institutions in the early 1998 has initiate the Malaysia government for a sudden decision for a bank merger programme in 1999 in order to consolidate the banking industry as some banking institutions faced difficulties due to their substantial losses and the increase of NPL ratios (Lum \& Koh 2007).

A robust bank merger programme was initiated by the government in July 1999 in order to restructure all domestic banking institutions into six banking groups (Lum \& Koh 2007). Referring to the Bank Negara Malaysia annual report 2001, there are ten lead anchor banks namely; Affin Bank Group, Alliance Bank Group, Arab Malaysia Bank Group, Bumiputra-Commerce Bank Group, EON Bank Group, Hong Leong Bank Group, Malaysian Banking Group, Public Bank Group, RHB Bank Group and Southern Bank Group. The composition of the ownership structure in the merged banking groups and the market structure of the banking industry usually changes due to the consolidation of the banking industry. The Malaysian government's strategy in the post-crisis years is to consolidate the banking industry (Lum \& Koh 2007).

As for the Malaysian banking sector, the changes in the ownership structure have been an important feature of the evolution. In Malaysia, the bank ownership structure implies a high concentration of shareholding by ownership types. The BAFIA was a clear and robust regulatory response to the crisis of the mid-1980s, which came into force on October 1, 1989.

As per Section 46 of BAFIA 1989, all banks are required to institutionalize their shareholding structure by restricting ownership in a bank by restrictive the limit of equity ownership by individual companies in bank to no more than 20 per cent as per the Banking act of 1973. On the other hand, the equity owned by family-owned company or an individual is restricted up to 10 per cent. However, it does seems to have any significant effect on the composition of ownership structure in the banking industry even though the consolidated programme have resulted in larger and better capitalized domestic banking institutions.

Empirically, the effect of ownership structure on firm performance was studied by (Demsetz \& Lehn 1985). This reason of the study mainly to set out the prediction by Berle and Means (1932) that diffuse ownership would adversely affect the firm performance. In corporate finance literature, 
the connection between ownership structure and performance has been the subject of an important and on-going debate (Demsetz \& Villalonga 2001).

There were researcher as early as 1932 like Berle and Means (1932) suggested that an inverse correlation could be observed of the diffuseness of shareholdings and firm performance while later this comment was argued by some other researchers (Demsetz and Lehn 1985; Himmelberg et al. 1999; Holderness and Sheehan 1988), who found concentrated ownership is not associated with better operating performance or high firm performance. Recently, there are more complex on the effect of ownership concentration on bank performance as showed by Laeven and Levine (2009) and Shehzad et al (2010). The argument raised by Laeven and Levine (2009) on the effectiveness of regulation, such as supervisory control and shareholder protection, is affected by ownership structure of the banks.

However, as ownership concentration reach greater than fifty per cent, the volume of nonperforming loans decreases (Shehzad, de Haan, \& Scholtens, 2010) . On the other hand, the approach by Laeven (1999) has consider different forms of bank ownership which include state-owned, foreignowned, company owned and family-owned banks, and excluding banks owned by institutional investors.

As per Demsetz and Villalonga (2001), the ownership structure and performance has been the subject of an important and on-going debate in the corporate finance literature which indicates in both in the developed and in the emerging countries. On the contrary, Galindo and Micco (2004), identified a strong relationship between ownership structure and performance only in emerging countries.

There are studies by (Agrawal and Knoeber 1996 ; Demsetz and Lehn 1985; Demsetz and Villalonga 2001) whereby the findings have no relationship between ownership and performance. However, while other studies such as (Hu and Izumida 2008; Kapopoulos and Lazaretou 2007; Morck et.al 1998), find that there is a relationship between ownership and performance.

Ownership is strongly correlated with bank performance (Micco, Panizza, \& Yañez, 2004). However, as in the industrial countries, the findings somehow show that ownership is not correlated with the bank performance. For the same reason, the issue raised and discussed by Barry, Lepetit, and Tarazi (2009) whereby ownership structure is of particular interest for the banking industry. This is due to several factors which interact and alter the governance such as the quality of the bank regulation and supervision and the opacity of bank assets.

Shrader, Blackburn, and lles (1997) and Lo (2003) use return on equity (ROE) as the operating performance. On the other hand, Brown and Caylor (2004) use return on equity and return on assets as their two operating performance measures. Meanwhile, Barnhart, Marr, and Rosenstein (1994) and Dowen (1995) and use market-to book value ratios as performance indicator. In the meantime, (Himmelberg et al. 1999; Lang and Stulz 1994; Mehran 1995) use Tobin's Q as the performance indicator.

As per Barry et al. (2009), the five categories of shareholders have been investigated are managers or directors, institutional investors, non-financial companies, individuals, families and banks. After controlling for several factors, the findings shows that asset risk is lower for banks where a higher proportion of total stocks is held by families and individuals who have less diversified 
portfolios. In addition to this, the finding shows that the probability of default of banks is higher when non-financial companies or institutional investors hold a higher proportion of total equity.

This research is more to the extension to the vast literature that looks upon on the relationship between the ownership structures with bank performances. Besides, the need of extension of the research due to fit the context of the country selected which is Malaysia as one of the emerging country. This research seems similar to prior research done by Demirgüç-Kunt and Huizinga (2000), which focus on an earlier period of (1988-1995 versus 1995-2002) on bank profitability. As for this research, the focus is on the Large Domestically-owned Commercial Banks (DCB) in Malaysia with more current period of from (2000-2012) for the bank operating performance ; return on asset and return on equity and Tobin's $Q$ as the market performance.

\subsection{Impact of Capital adequacy ratio on the ownership structure - bank performance link}

The capital adequacy refers to a bank's capital or equity whereby it is the margin by which creditors are covered if the bank has to liquidate its assets. Capital to asset ratio, is a good measure of a bank's health, which by law, is required to be above a prescribed minimum. The current minimums of capital adequacy ratios are as in the following. As in Tier one, the total risk weighted must not be less than four per cent. Meanwhile, the total capital which comprises Tier one and Tier two to total risk weighted must not be less than eight per cent.

In Malaysia, prior to the onset of the financial crisis in 1997, BNM imposed caps on lending to the broad property sectors and on share financing. The caps were based on the respective institution's total loan outstanding and were put in place to ensure that these sectors' risk exposures were within manageable limits without posing any excessive risks to the banking system (Lum \& Koh 2007). In order to limit the risk and limitations on charges, a common feature of adjustable rate mortgages known as 'cap' is introduce in the industry.

A bank's lending is ultimately limited by the amount of its own capital (assets minus liabilities). The capital adequacy rule requires that the ratio of its capital to risk-weighted assets be at least eight per cent. According to Naceur and Kandil (2009), as the capital adequacy ratio internalizes the risk for shareholders, banks tend to increase the cost of intermediation. As the result, the situation supports higher return on assets as well as to return on equity.

Capital, in general serves as a buffer against losses and failure. Major reformations are required in addressing weak banking supervision and inadequate capital by many developing countries which have experienced banking problems. Besides, as for deposit insurance, in aligning the incentives of bank owners with depositors and creditors, official capital adequacy regulations play a crucial role. Conflicting predictions by theory do provide whether capital requirement curtail or promote bank performance and stability.

The importance of the soundness of the banking system is due to avoiding adverse budgetary consequences for governments, which often bear a significant part of the costs of bailouts and limiting economic downturns related to financial panics. In order to protect the banking system from the former problems is through prudential regulation which is meant to induce banks to invest prudently. The reason is since capital requirement is a form of one of the prudential regulation.

A higher capital requirements in the post-regulation period, is one of the factor which contribute positively to the banks' profitability. Capital requirement ratios in banks can be fulfil by 
reducing their risk-weighted assets or by increasing their capital. Besides, according to existing literature by Molyneux and Thornton (1992), show-there is a relationship between return on equity and capital adequacy. On the other hand, according to Jones, Miller, and Yeager (2011), banks with higher Tobin's Q held higher levels of capital.

Thus, we hypothesized that Capital Adequacy Ratio (CAR) moderates the relationship between bank profitability and ownership structure.

\section{Conceptual Framework and Methodology}

The data used in this study consist of annual ownership and financial data for the eight listed commercial banks in Malaysia during the years 2000-2012. The banks included in the sample are AMMB, HLB, Public Bank RHB, Affin, CIMB, Maybank and Alliance Bank. The data have been gathered from annual reports of the banks, Thomson Financial Datastream data services and Bureau Van Dijk Bankscope/Orbis Bank Focus.

Usable data for analysis are from 2000-2016 due to the bank merger and acquisition process completed by 2001 . Thus, in order to test both of the models in this research; a balanced panel of data is constructed by collecting yearly data from 2000 until 2016 of eight large domestically-owned commercial banks in Malaysia which consists of 104 observations.

Three measures of bank performance are employed and they are return on assets (ROA), return on equity (ROE) and Tobin's $Q$. Return on Assets (ROA) measures how profitable a company is relative to its total assets. It also measures how efficiently a company uses it assets.

Referring to Kang and Shivdasani (1995), return on assets is the industry-adjusted ratio of pre-tax operating income to total assets. It is an accounting-based measure of performance. Beside, this short-term profitability of the firms' operations is a variable which is not sensitive to tax effects and changes in capital structure. Therefore, following this argument, ROA as a proxy of profitability value is the ratio of earnings before interest and tax (EBIT) to total assets.

One of the primary reasons for operating a corporation is to generate income for the benefit of the common stockholders. Return on equity is a measure that shows an investor how much profit a company generates from the money invested from its shareholders. Epps and Cereola (2008) suggest that ROE is defined as the income before extraordinary items available for common equity divided by the sum of the book value of equity and deferred taxes. ROE is therefore calculated as the ratio of net income to total equity.

The third measure of performance, Tobin's $Q$ is the ratio between the market value and the replacement value of the same physical asset. The Tobin's $Q$ ratio is a measure of firm assets in relation to a firm's market value. In this research, the measurement of Tobin's $Q$ is based on prior study by Andres and Vallelado (2008). The company is considered undervalued when Tobin's Q ratio is less than 1, which indicates that the market value of the company is less than the total asset value. Similarly, the company is considered overvalued when Tobin's $Q$ ratio is more than 1 , which indicates that the market value of the company is higher than the total asset value.

According to James Tobin, Yale university economist, the firm has done well with its investment decision, when a Tobin's $Q$ ratio of the firm greater than 1 . Following prior studies, this 
current study uses the ratio of total market value to total asset value as a measure of Tobin's $Q$. Thus for this research, Tobin's $Q$ value is calculated as:

TOBIN'S Q = (Total Asset -Common Equity + Market Capitalization) / Total Asset

Ownership-specific determinants of bank performance behaviour are government ownership, institutional ownership and family ownership are employed in this study. The ownership structure is based on the total accumulation percentage of top 30 shareholders which are gain from the annual reports of the eight banks from 2000 to 2012.

In addition, bank size (BNKSIZE) and leverage (LVRG), are employed as control variables. Finally, capital adequacy ratio (CAR) is included as the moderating variable.

Bank size (BNKSIZE) is represented by the natural logarithm of bank total assets as prior research by (Brown \& Caylor, 2006). Following Lee et al. (2008), bank's leverage (LVRG) is measured by capital to asset ratio, and leverage value is represented by the ratio of total debt to common equity. Capital adequacy requirements set by central banks are intended to reduce bank insolvency risk is calculated as the ratio of total capital to risk weighted assets of banks.

3.1 The impact of ownership structure on bank performance with CAR

To perform the analyses on the link of ownership structures and the bank performance, two main models have been proposed for each of the bank performance regression. In the first model, the variables comprise of the three ownerships, CAR and the two control variables are included in the model. As for the second model, the interaction of CAR and the three ownerships are introduced. The models are as below:

Model 1

Performance $=?_{0}+?_{1} \mathrm{GOVOWN}_{\mathrm{it}}+$ ? $_{2} \mathrm{INSTOWN}_{\mathrm{it}}+$ ? $_{3} \mathrm{FAMOWN}_{\mathrm{it}}+$ ? $_{4} \mathrm{CAR}_{\mathrm{it}}+$ ? $\mathrm{l}_{5} \mathrm{BNKSIZE}_{\mathrm{it}}+?_{6} \mathrm{LVRG}_{\mathrm{it}}+$ $\sum_{j=1}^{7} \gamma_{j} D B_{j}+\mathrm{e}_{i \mathrm{t}}$

Model 2

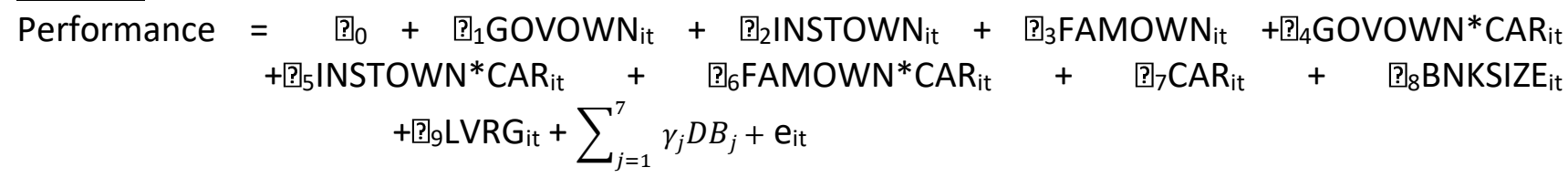

where, performance are measured by ROA , ROE and Tobin's Q. GOVOWN, INSTOWN and FAMOWN are ownership structure variables and $C A$ ) is the capital adequacy ratio. BNKSIZE and LVRG are the control variables. $D B_{j}$ is a bank dummy variable. Finally, as for the second step of the hierarchical regression, represented by Model 2, the interaction between the three independent variables and the moderating variable (CAR) are included in the regression. This model assumes that capital adequacy ratio (CAR) as moderating variable has an impact on the dependent variable; ROA, ROE and Tobin's $Q$, through its interaction with the independent variables.

\section{Empirical Results}

Summary of the sample descriptive statistics of ownership structure variables, risk measure, moderating variable, and control variables for the sample of eight commercial banks are presented in Table 1. Total number of observations in this study for each variable is 104 , which came in the form 
INTERNATIONAL JOURNAL OF ACADEMIC RESEARCH IN BUSINESS AND SOCIAL SCIENCES

Vol. 8, No. 10, Oct. 2018, E-ISSN: 222 2-6990 @ 2018 HRMARS

of a panel data of eight cross sections (i.e. commercial banks) and time series of thirteen years. Panels of data are all balanced with no missing data. For the ownership -structure, GOVOWN has the largest mean with value of 18.24 per cent, followed by INSTOWN(7.28 per cent) and FAMOWN (2.97 per cent).

Table 1. Descriptive Statistics for the Variables of the Study

\begin{tabular}{|l|l|l|l|l|l|l|}
\hline & Mean & Median & Min & Max & Std.Dev. & Observ. \\
\hline GOVOWN & 0.1824 & 0.1551 & 0 & 0.8166 & 0.1738 & 104 \\
\hline INSTOWN & 0.0728 & 0.0028 & 0 & 0.3364 & 0.0999 & 104 \\
\hline FAMOWN & 0.0297 & 0.0092 & 0 & 0.354 & 0.0579 & 104 \\
\hline BNKSIZE & 18.1713 & 18.1660 & 13.9691 & 20.0172 & 0.8958 & 104 \\
\hline LVRG & 2.1527 & 1.7477 & 0.2541 & 8.7467 & 1.5059 & 104 \\
\hline CAR & 0.1466 & 0.1449 & 0.1155 & 0.2380 & 0.0208 & 104 \\
\hline ROA & 0.0126 & 0.0131 & -0.0185 & 0.0284 & 0.0064 & 104 \\
\hline ROE & 0.1074 & 0.1136 & -0.3479 & 0.2844 & 0.0769 & 104 \\
\hline TOBIN'S Q & 1.0556 & 1.0551 & 0.9418 & 1.7430 & 0.0858 & 104 \\
\hline
\end{tabular}

This table provides some descriptive statistics on the sample of 8 domestic commercial banks in Malaysia. We report the mean, median, minimum value, maximum value and standard deviation of variables used in the regression.

The mean for the moderating variable (CAR) is 14.66 percent, with maximum of 23.8 per cent and minimum of 11.55 per cent which are all above the capital requirement of 8 percent as set by the central bank BNM. On the other hand, ROA with the mean value of 1.26 per cent and maximum of 2.83 per cent indicate that the sample of the banks are not efficient about using its assets compare to banks with a good ROA of more than 5 per cent. Even though the mean of ROE is 10.73 per cent, the maximum of the ROE of 28.44 per cent reflect how much profit the banks generate from the money invested from the shareholders. The market performance measured by Tobin's $Q$ with the mean of 1.556 and with maximum of 1.743 reflects that the measure of the bank's asset in relation to the bank market value is overvalued.

The estimation approach applied here is the Least Square with bank dummy variables (LSDV). The dummies were included to allow for heterogeneity across the sample banks. To test for this heterogeneity, the Wald test is performed on the data. Table 2 below presents the F-statistics of the Wald test. For Model 1, the F-statistics values are all significant at 1 percent level of significance. This indicates that these sample banks indeed have different intercepts, or simply there exists a fixed effect across the sample banks. However, when CAR is allowed to interact with the ownership variables, Model 2 becomes insignificant when ROA is used to represent the performance measure. Two other measures of performance of Model 2, are significant at least at 5 percent level. 
INTERNATIONAL JOURNAL OF ACADEMIC RESEARCH IN BUSINESS AND SOCIAL SCIENCES Vol. 8, No. 10, Oct. 2018, E-ISSN: 2222-6990 @ 2018 HRMARS

Table 2: Wald Test for the Least Square Dummy Variables (LSDV)

\begin{tabular}{|l|l|l|l|l|l|l|}
\hline & Model 1 & Model 2 & Model 1 & Model 2 & Model 1 & Model 2 \\
\hline Dep. Var & ROA & \multicolumn{2}{l|}{ ROE } & Tobin's Q & \\
\hline F-statistic & $3.60^{* * *}$ & 1.40 & $3.20^{* * *}$ & $2.68^{* *}$ & $15.60^{* * *}$ & $12.27^{* * *}$ \\
\hline
\end{tabular}

Note:

Single asterisk $\left({ }^{*}\right)$ indicates significant at 10 percent level, double asterisks $\left({ }^{* *}\right)$ indicate significant at 5 percent level, and triple asterisks $\left({ }^{* * *}\right)$ indicate significant at 1 percent level.

Results of the Least Square Dummy Variables (LSDV) regression analysis for all the three bank performance models are presented in Table 3.

Table 3. Regression Results for the Models

\begin{tabular}{|c|c|c|c|c|c|c|}
\hline Variables & Model 1 & Model 2 & Model 1 & Model 2 & Model 1 & Model 2 \\
\hline Dep. Var & \multicolumn{2}{|l|}{ ROA } & \multicolumn{2}{|l|}{ ROE } & \multicolumn{2}{|l|}{ Tobin's Q } \\
\hline Constant & $\begin{array}{l}0.2773 \\
(1.16) \\
\end{array}$ & $\begin{array}{l}-0.0116 \\
(-0.44) \\
\end{array}$ & $\begin{array}{l}-0.3479 \\
(-1.25) \\
\end{array}$ & $\begin{array}{l}-0.6741 \\
(-2.10)^{* *}\end{array}$ & $\begin{array}{l}2.1740 \\
(9.34)^{* * *}\end{array}$ & $\begin{array}{l}2.1356 \\
(7.92)^{* * *}\end{array}$ \\
\hline GOVOWN & $\begin{array}{l}-0.0015 \\
(-0.30)\end{array}$ & $\begin{array}{l}0.0719 \\
(2.51)^{* *}\end{array}$ & $\begin{array}{l}-0.0290 \\
(-0.49)\end{array}$ & $\begin{array}{l}0.3659 \\
(1.07)\end{array}$ & $\begin{array}{l}0.0163 \\
(0.33)\end{array}$ & $\begin{array}{l}-0.4552 \\
(-1.58)\end{array}$ \\
\hline INSTOWN & $\begin{array}{l}-0.0342 \\
(-2.14)^{* *}\end{array}$ & $\begin{array}{l}-0.0292 \\
(-0.58)\end{array}$ & $\begin{array}{l}-0.2886 \\
(-1.56)\end{array}$ & $\begin{array}{l}0.1960 \\
(0.33)\end{array}$ & $\begin{array}{l}-0.9369 \\
(-6.03)^{* * *}\end{array}$ & $\begin{array}{l}-0.7574 \\
(-1.50)\end{array}$ \\
\hline FAMOWN & $\begin{array}{l}0.0129 \\
(1.05) \\
\end{array}$ & $\begin{array}{l}0.3303 \\
(2.33)^{* *}\end{array}$ & $\begin{array}{l}0.2589 \\
(1.82)^{*}\end{array}$ & $\begin{array}{l}3.5091 \\
(2.06)^{* *}\end{array}$ & $\begin{array}{l}0.6052 \\
(5.06)^{* * *}\end{array}$ & $\begin{array}{l}1.8461 \\
(1.29)\end{array}$ \\
\hline CAR & $\begin{array}{l}0.0168 \\
(0.52)\end{array}$ & $\begin{array}{l}0.1011 \\
(1.60)\end{array}$ & $\begin{array}{l}-0.5848 \\
(-1.57)\end{array}$ & $\begin{array}{l}0.3530 \\
(0.47)\end{array}$ & $\begin{array}{l}-0.2609 \\
(-0.84)\end{array}$ & $\begin{array}{l}-0.4386 \\
(-0.69)\end{array}$ \\
\hline BNKSIZE & $\begin{array}{l}-0.0006 \\
(-0.55) \\
\end{array}$ & $\begin{array}{l}0.0009 \\
(0.68) \\
\end{array}$ & $\begin{array}{l}0.0304 \\
(2.31)^{* *}\end{array}$ & $\begin{array}{l}0.0408 \\
(2.61)^{* *}\end{array}$ & $\begin{array}{l}-0.0536 \\
(-4.86)^{* * *}\end{array}$ & $\begin{array}{l}-0.0507 \\
(-3.85)^{* * *}\end{array}$ \\
\hline LVRG & $\begin{array}{l}-0.0012 \\
(-2.33)^{* *}\end{array}$ & $\begin{array}{l}-0.0015 \\
(-2.84)^{* * *}\end{array}$ & $\begin{array}{l}-0.0055 \\
(-0.89)\end{array}$ & $\begin{array}{l}-0.0078 \\
(-1.21)\end{array}$ & $\begin{array}{l}-0.0059 \\
(-1.13)\end{array}$ & $\begin{array}{l}-0.0073 \\
(1.34)\end{array}$ \\
\hline GOVOWN*CAR & & $\begin{array}{l}-0.5479 \\
(-2.59)^{* *}\end{array}$ & & $\begin{array}{l}-2.8543 \\
(-1.13)\end{array}$ & & $\begin{array}{l}3.6168 \\
(1.70)^{*}\end{array}$ \\
\hline INSTOWN*CAR & & $\begin{array}{l}0.0503 \\
(0.16)\end{array}$ & & $\begin{array}{l}-2.6332 \\
(-0.71)\end{array}$ & & $\begin{array}{l}-1.4727 \\
(-0.47)\end{array}$ \\
\hline FAMOWN*CAR & & $\begin{array}{l}-2.3453 \\
(-2.22)^{* *}\end{array}$ & & $\begin{array}{l}-24.2525 \\
(-1.92)^{*}\end{array}$ & & $\begin{array}{l}-9.4827 \\
(-0.89)\end{array}$ \\
\hline Affin & $\begin{array}{l}-0.0012 \\
(-0.25) \\
\end{array}$ & $\begin{array}{l}-0.0005 \\
(0.68) \\
\end{array}$ & $\begin{array}{l}0.0292 \\
(0.51) \\
\end{array}$ & $\begin{array}{l}0.0259 \\
(0.44) \\
\end{array}$ & $\begin{array}{l}0.0029 \\
(0.06)\end{array}$ & $\begin{array}{l}0.0043 \\
(0.09)\end{array}$ \\
\hline Alliance & $\begin{array}{l}-0.0039 \\
(-0.92)\end{array}$ & $\begin{array}{l}-0.0039 \\
(-0.88)\end{array}$ & $\begin{array}{l}0.0327 \\
(0.66)\end{array}$ & $\begin{array}{l}0.0332 \\
(0.62)\end{array}$ & $\begin{array}{l}-0.0534 \\
(-1.28)\end{array}$ & $\begin{array}{l}-0.0341 \\
(-0.76)\end{array}$ \\
\hline AMMB & $\begin{array}{l}-0.0021 \\
(-0.77) \\
\end{array}$ & $\begin{array}{l}-0.0016 \\
(-0.60) \\
\end{array}$ & $\begin{array}{l}-0.0169 \\
(-0.54) \\
\end{array}$ & $\begin{array}{l}-0.0069 \\
(-0.21) \\
\end{array}$ & $\begin{array}{l}0.1567 \\
(-5.94)^{* * *}\end{array}$ & $\begin{array}{l}-0.1434 \\
(-5.25)^{* * *}\end{array}$ \\
\hline CIMB & $\begin{array}{l}-0.0018 \\
(-0.79)\end{array}$ & $\begin{array}{l}-0.0013 \\
(-0.61)\end{array}$ & $\begin{array}{l}-0.0031 \\
(-0.12)\end{array}$ & $\begin{array}{l}0.0001 \\
(0.01)\end{array}$ & $\begin{array}{l}-0.0448 \\
(-2.06)^{* *}\end{array}$ & $\begin{array}{l}-0.0453 \\
(-2.09)^{* *}\end{array}$ \\
\hline HLB & $\begin{array}{l}-0.0045 \\
(-1.67)^{*}\end{array}$ & $\begin{array}{l}-0.0017 \\
(-0.55) \\
\end{array}$ & $\begin{array}{l}0.0310 \\
(0.99) \\
\end{array}$ & $\begin{array}{l}0.0582 \\
(1.52) \\
\end{array}$ & $\begin{array}{l}-0.1250 \\
(4.78)^{* * *}\end{array}$ & $\begin{array}{l}-0.1038 \\
(-3.23)^{* * *}\end{array}$ \\
\hline PBB & $\begin{array}{l}0.0088 \\
(2.31)^{* *}\end{array}$ & $\begin{array}{l}0.0050 \\
(1.29) \\
\end{array}$ & $\begin{array}{l}0.1246 \\
(2.85)^{* *}\end{array}$ & $\begin{array}{l}0.1055 \\
(2.27)^{* *}\end{array}$ & $\begin{array}{l}0.1362 \\
(3.70)^{* * *}\end{array}$ & $\begin{array}{l}0.1593 \\
(4.08)^{* * *}\end{array}$ \\
\hline $\mathrm{RHB}$ & $\begin{array}{l}-0.0039 \\
(-1.61)\end{array}$ & $\begin{array}{l}-0.0034 \\
(-1.36)\end{array}$ & $\begin{array}{l}-0.0405 \\
(-1.46)\end{array}$ & $\begin{array}{l}-0.0291 \\
(-0.97)\end{array}$ & $\begin{array}{l}-0.1285 \\
(-5.52)^{* * *}\end{array}$ & $\begin{array}{l}-0.1111 \\
(-4.41)^{* * *}\end{array}$ \\
\hline Adj. $R^{2}$ & 0.3305 & 0.3865 & 0.3720 & 0.3830 & 0.6440 & 0.6490 \\
\hline F-Statistics & $4.91 * * *$ & $5.06 * * *$ & $5.69 * * *$ & $5.00 * * *$ & $15.34 * * *$ & $12.90 * * *$ \\
\hline $\mathrm{N}$ & 104 & 104 & 104 & 104 & 104 & 104 \\
\hline
\end{tabular}


Note:

1. Single asterisk $\left({ }^{*}\right)$ indicates significant at 10 percent level, double asterisks (**) indicate significant at 5 percent level, and triple asterisks $\left({ }^{* *}\right)$ indicate significant at 1 percent level.

2. F-test statistics in the above table are all significant at $1 \%$ level of significance. This indicates that all the coefficients in the model are different from zero, and hence the overall model used in the relationship is fit.

3. Maybank is taken as the reference bank which is selected based on its high total asset during the whole period of study.

For Model 1, CAR is not significant for all measures of performance. As for the ownership structure variables, government-ownership which is represented by GOVOWN is not significant regardless of the measure of performance employed. Institutional-ownership (INSTOWN) is significant at $5 \%$ with performance measure ROA and at $1 \%$ when Tobin's $Q$ is the performance measure, and this level of significant for Tobin's $Q$ can also be found for the family-ownership variable (FAMOWN). FAMOWN is also significant at $10 \%$ when ROE is the performance measure. Control variable BNKSIZE is found to be positively significant at $5 \%$ level with ROE but negatively significant at $1 \%$ level with Tobin's $Q$. The second control variable, leverage (LVRG), is negatively significant at $5 \%$ level with ROA, but insignificant with the other two measures of performance.

For all measures of performance, PBB appears to be positively significant different from Maybank, which is the reference bank, in this study. HLB is negatively significant different from the reference bank at $10 \%$ level when ROA is used to represent the performance measure. When Tobin's $Q$ is used as the performance measure, only Affin and Alliance are not significant different from Maybank.

As presented earlier, Model 2 examines the impact of the interactions between ownershipstructure variables and capital adequacy ratio (CAR) on bank performance. Consistent with the results of Model 1, CAR is insignificant for all measures of performance. However, when CAR interacts with GOVOWN and FAMOWN, it produces negative significant results at $5 \%$ level for ROA. The interaction of CAR with FAMOWN also produces negative significant result for ROE. Unlike negative significant relationship with ROA when CAR interacts with GOVOWN, this interaction is positive when performance is measured by Tobin's $Q$.

As mentioned earlier, the sample banks have different intercepts, or simply there exists a fixed effect across the sample banks, only when ROE and Tobin's $Q$ are the measures of performance. For ROE, only PBB is positively significant different from the reference bank, and PBB retains this even when Tobin's $Q$ is the measure of performance. Further, consistent with Model 1, only Affin and Alliance are not significantly different with the reference bank.

Given the potential interrelationships among the explanatory variables, a pairwise correlation of independent variables included in the regression model was performed. The correlation coefficients for all the explanatory variables are presented in Table 4. None of the explanatory variables has coefficient greater than \pm 0.8 . Given this results, the problem of multicollinearity in the regression model can be ruled out. 
INTERNATIONAL JOURNAL OF ACADEMIC RESEARCH IN BUSINESS AND SOCIAL SCIENCES

Vol. 8, No. 10, Oct. 2018, E-ISSN: 222 2-6990 @ 2018 HRMARS

Table 4: Correlation Matrix

\begin{tabular}{|c|c|c|c|c|c|c|}
\hline & & & & & BNK & \\
\hline & \multicolumn{6}{|c|}{ GOV INST FAM CAR } \\
\hline GOV & \multicolumn{6}{|l|}{1} \\
\hline \multirow[t]{2}{*}{ INST } & \multicolumn{6}{|c|}{0.14521} \\
\hline & - & - & & & & \\
\hline \multirow[t]{2}{*}{ FAM } & \multicolumn{6}{|c|}{0.33350 .17671} \\
\hline & \multicolumn{6}{|c|}{$\begin{array}{ll}- & -\end{array}$} \\
\hline \multirow[t]{2}{*}{ CAR } & \multicolumn{6}{|c|}{0.19660 .21160 .18341} \\
\hline & & - & - & & & \\
\hline \multirow[t]{2}{*}{ BNKSIZE } & \multicolumn{6}{|c|}{0.10040 .39000 .35780 .00311} \\
\hline & & - & & - & & \\
\hline LVRG & 0.019 & 40.246 & 10.434 & 30.46 & $4-0.0814$ & 1 \\
\hline
\end{tabular}

\section{Conclusion}

Family ownership is significant towards return on asset (ROA). PBB and RHB which are classified as family owned banks are significant towards ROA. However, the other two family owned banks; $A M M B$ and HLB are not significant towards ROA. Besides, Maybank as the reference bank is also significant towards ROA. Although AMMB and HLB are family owned banks, one can conclude that it is not necessary significant towards ROA, even though family ownership is significant towards ROA as a whole. This is due to the high fraction of institutional shareholding in both of the banks. As for Maybank, the increase in institutional ownership and decrease in government ownership by years contribute to the result of Maybank is significant towards ROA although government ownership structure is not significant towards ROA.

Although none of the three ownership structure; government, institutional and family are significant towards return on equity (ROE), PBB and RHB which are family owned banks are significant towards ROE. This implies that the performance of bank ROE is not influenced by the ownership structure, or in other word, the ownership structure is not the factor in affecting for the performance of ROE in banks.

As for the market performance measured by Tobin's $Q$, the three ownership structures are found to be the determinant towards the performance of Tobin's Q. All the banks regardless of the bank owned type are found to be significant towards Tobin's Q except for HLB and PBB, which are family owned banks, even though family ownership structure is found to be significant towards Tobin's Q. This imply that the three ownership structure are not the determinant for HLB and PBB towards the performance of Tobin's Q. Overall, only RHB which is classified as the family owned bank is significant towards ROA, ROE and Tobin's $Q$, in any condition of whether ownership structure are significant or not significant towards these three bank performance. This is due to the fraction of shareholdings in RHB which contribute to the significant of the result.

Capital adequacy ratio (CAR) is found to be significant as a moderating factor towards the performance of ROA. This is supported by the significant implication of CAR as moderating element for Maybank, Affin, Alliance CIMB and HLB towards the performance of ROA. Besides, it is found that 
all the ROA for government owned banks performance are being influenced by CAR in moderating the bank ROA. As for AMMB, PBB, and RHB, which are categorized as family owned bank, imply that $C A R$ is not relevant in intervening the ROA performance of these three banks.

Besides, CAR is found to be significant as a moderating factor towards ROE for Maybank, Alliance and HLB. The remaining banks which comprise of the two government owned banks; Affin and $\mathrm{CIMB}$ and family owned banks; $\mathrm{AMMB}, \mathrm{PBB}$ and $\mathrm{RHB}$, these banks are not affected by the intervening of CAR towards the performance of ROE. In addition, CAR is found to be the factor moderating the performance of Tobin's $Q$ for all the banks except for Alliance and HLB. CAR is most significant as a moderating factor towards Tobin's $Q$ for Maybank, AMMB, CIMB, PBB and RHB. Overall, CAR is significant as the moderating for Maybank for both the operating performance; ROA and ROE, as well towards the market performance; Tobin's Q. Besides, the performance of ROE of the overall banks is due to the positive interaction between the three ownership structure and CAR as supported in prior research hypothesis.

From the findings of this study it help to improve the understanding of the role of ownership structures namely; government ownership, institutional ownership and family ownership in determining the performance of commercial banks in Malaysia. It is found that the direction of the individual ownership structure is not the main influence towards the performance of individual commercial bank in Malaysia. This is due to the role of CAR as the moderating factor in moderating the effect of the ownership structure and the bank performance whether in negative or positive direction of CAR.

In addition, this research also contributes to the knowledge of how the three main group of commercial banks (family owned banks, government owned banks and institutional owned banks) which comprise of 8 banks; (Affin, Alliance, AMMB, CIMB, HLB, Maybank, PBB and RHB) with the twooperating performance (ROA and ROE) and with the market performance. This is through the effect between the three ownership structures towards the bank performance along with the moderating variable, control variables and interaction variables.

\section{References}

Ahn, S., \& Choi, W. (2009). The role of bank monitoring in corporate governance: Evidence from borrowers' earnings management behaviour. Journal of Banking \& Finance, 33(2), 425-434.

Altunbas, Y., Evans, L., \& Molyneux, P. (2001). Bank ownership and efficiency. Journal of Money, Credit and Banking, 33(4), 926-954.

Andres, P.D. \& Vallelado,E. (2008). Corporate Governance in Banking: The Role of the Board of Directors. Journal of Banking \& Finance, 32(12), 2570-2580.

Angbazo, L. (1997). Commercial bank net interest income, default risk, interest-rate risk, and off-balance sheet banking. Journal of Banking \& Finance, 21(1), 55-87.

Barry,T.A.,Lepetit, L. \& Tarazi, A. (2009). Bank Ownership Structure, Market Discipline and Risk : Evidence from a Sample of Privately Owned and Publicly Held European Banks. http://papers .ssrn.com/sol3/papers.cfm?abstract_id=1331154 [1 November 2009]. 
INTERNATIONAL JOURNAL OF ACADEMIC RESEARCH IN BUSINESS AND SOCIAL SCIENCES

Vol. 8, No. 10, Oct. 2018, E-ISSN: 222 2-6990 @ 2018 HRMARS

Beck, T., Demirguc-Kunt, A., \& Levine, R. (2003). Bank concentration and crises . National Bureau of Economic Research Working Paper Series No. 9921. [Online] Available : http: // www.nber.org/papers/w9921 (August, 2003).

Beck, T., Demirguc-Kunt, A., \& Levine, R. (2006). Bank concentration, competition, and crises: First results. Journal of Banking \& Finance, 30(5), 1581-1503.

Beck, T., Hesse, H., Kick, T., \& Westernhagen, N. V. (2009). Bank ownership and stability :

Evidence from Germany. [Online] Available : https://www.fdic.gov/bank/ analytical /cfr/2009/june/CFR_SS_2009_beck.pdf. (April, 2009).

Berle, A. \& Means, G.(1932). The Modern Corporation and Private Property. New York: Harcourt, Brace \& World. and off-balance sheet banking. Journal of Banking \& Finance, 21(1), 55-87.

Brown, L.D. \& Caylor, M.L. (2006). Corporate Governance and Firm Valuation. Journal of Accounting and Public Policy, 25(4), 409-434.

Demirguc-Kunt, A. \& Huizinga, H. (2000). Financial Structure and Bank Profitability. World Bank Policy Research Workingh Paper No. 2430. http://papers. ssrn.com/sol3/papers.cfm?abstract_id=632501 [August 2000].

Demsetz, H., \& Lehn, K. (1985). The structure of corporate ownership: Causes and consequences. Journal of Political Economy, 93(6), 1155-1177.

Demsetz, H. \& Villalonga, B. (2001). Ownership Structure and Corporate Performance. Journal of Corporate Finance, 7(3), 209-233.

Deyoung, R. (2012). Nontraditional Banking Activities and Bank Failures During the Financial Crisis . Journal of Financial Intermedian, 22(3), 397-421.

Dugan, J. C. (2009). Loan loss provisioning and pro-cyclicality. [Online] Available : http//www.occ.gov/news-issuances/speeches/2009/pub-speech-2009-16.pdf. (March 2, 2009).

Epps, R. W. \& Cereola, S. J. (2008). Do Institutional Shareholder Services (ISS) Corporate Governance Ratings Reflect a Company's Operating Performance? Critical Perspectives on Accounting, 19(8), 1135-1148.

Galindo, A. \& Micco, A.(2004). Do State Owned Banks Promote Growth? Cross-Country Evidence for Manufacturing Industries. Economic Letters, 84(3): 371-376.

Hassan, M. K. (1993). Capital market tests of risk exposure of loan sales activities of large U.S. Commercial banks. Quarterly Journal of Business and Economics, 32(1), 27-49.

Holderness, C. G. \& Sheehan, D.P.(1988). The Role of Majority Shareholders in Publicly Held Corporations: An Exploratory Analysis. Journal of Financial Economics, 20(0): 317-346.

Hu, Y. \& Izumida, S. (2008). Ownership Concentration and Corporate Performance : A Causal Analysis with Japanese Panel Data. Corporate Governance: An International Review, 16(4), 342-358.

Iannotta, G., Nocera, G., \& Sironi, A. (2007). Ownership structure, risk and performance in the European banking industry. Journal of Banking \&amp; Finance, 31(7), 21272149. 
INTERNATIONAL JOURNAL OF ACADEMIC RESEARCH IN BUSINESS AND SOCIAL SCIENCES

Vol. 8, No. 10, Oct. 2018, E-ISSN: 222 2-6990 @ 2018 HRMARS

Jones, J.S., Miller, S.A. \& Yeager, T. J. (2011). Charter Value, Tobin's Q and Bank Risk During the Subprime Financial Crisis. Journal of Economic and Business, 63(5), 372391.

Kang, J.-K. \& Shivdasani, A. (1995). Firm Performance, Corporate Governance, and Top Executive Turnover in Japan. Journal of Financial Economics, 38(1), 29-58.

Kapopoulos, P. \& Lazaretou, S. (2007). Corporate Ownership Structure and Firm Performance: Evidence from Greek Firms . Corporate Governance: An International Review, 15(2), 144-158.

Laeven, L., \& Levine, R. (2009). Bank governance, regulation and risk taking. Journal of Financial Economics, 93(2), 259-275.

Laeven, L.A. (1999). Risk and Efficiency in the East Asian Banks. World Bank Policy Research Working Paper $\quad$ No. 2255 http://papers.ssrn.com/sol3/papers.cfm?abstract id=629192 [December 1999].

Lee, K., Lev, B., \& Yeo, G. (2008). Executve pay dispersion, corporate governance, and firm performance. Review of Quantitative Finance and Accounting, 30(3), 315-338.

Levine, R. (2004). The corporate governance of banks: A concise discussion of concepts and evidence. World bank policy research working paper 3404. [Online] Available : http://books.google. com. my/books?id $=$ CPIDv2OzdgC\&dq $=$ The + Corporate+ Governance +of+ Banks:+ A+Concise + Discussion + of + Concepts+and + Evidence. \&Ir=\&source =gbs_navlinks_s. (September, 2004).

Lum, C. S., \& Koh, P. T. N. (2007). Corporate governance of banks in Malaysia. [Online] Available : http://www.ibbm.org.my/pdf/KRBJM003\%20Philip.pdf. (2007).

Madura, J., Martin, A. D., \& Taylor, D. A. (1994). Determinants of implied risk at depository institutions. Applied Financial Economics 4, 363-370.

Micco, A., Panizza, U.G. \& Yanez, M. (2004). Bank Ownership and Performance. http://papers.ssrn.com/sol3/papers.cfm?abstract id=1818718 [November 2004].

Morck, R., Shleifer, A. \& Vishny, R. W. (1988). Management Ownership and Market Valuation: An Empirical Analysis. Journal of Financial Economics, 20(0), 293-315.

Naceur, S. B., \& Kandil, M. (2009). The impact of capital requirements on banks' cost of intermediation and performance : The case of Egypt. Journal of Economics and Business, 61(1), 70-89.

Riewsathirathon, P., Jumroenvong, S. \& Jirapom, P. (2011). The Impact of Ownership Concentrationon Bank Performance and Risk Taking : Evidence from East Asia. http://cms.tbs.tu.ac.th/medias/BRC/Seksak.pdf [8 March 2011].

Shehzad, C. T., de Haan, J., \& Scholtens, B. (2010). The impact of bank ownership concentration on impared loans and capital adequacy. Journal of Banking \&amp; Finance, 34(2), 399-408.

Williams, J., \& Nguyen, N. (2005). Financial liberalisation, crisis, and restructuring: A comparative study of bank performance and bank governance in South East Asia. Journal of Banking and Finance, 29(8-9 SPEC. ISS.), 2119-2154. 